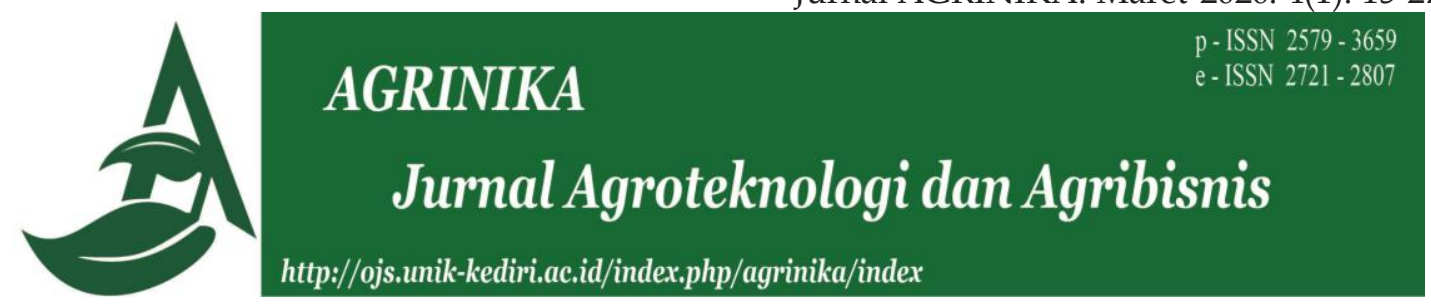

\title{
Diversitas Mikrofungi Zona Intertidal dan Subtidal Pantai Barat Pananjung Pangandaran
}

\author{
Putri Kumala Dewi ${ }^{1 *}$, Nia Rossiana ${ }^{1}$, dan Ida Indrawati ${ }^{1}$ \\ ${ }^{1}$ Fakultas Matematika dan Ilmu Pengetahuan Alam,Universitas Padjadjaran, Sumedang, \\ Indonesia \\ *Korespondensi : putrikumaladewi30@gmail.com
}

Diterima 6 Januari 2020/Direvisi 15 Februari 2020/Disetujui 21 Februari 2020

\begin{abstract}
ABSTRAK
Kawasan laut Pantai Barat Pananjung Pangandaran merupakan salah satu kawasan perairan laut yang memiliki tingkat biodiversitas yang tinggi khususnya mikroorganisme. Pada pantai Barat Pananjung Pangandaran Zona intertidal diindikasikan memiliki tingkat pencemaran akibat pola kegiatan manusia jauh lebih tinggi dari pada zona subtidal sehingga mempengaruhi keberadaan mikroorganisme khususnya mikrofungi. Tujuan dari penelitian ini adalah untuk mengisolasi dan mengidentifikasi mikrofungi yang terdapat pada perairan zona intertidal dan subtidal pantai Barat Pananjung Pangandaran. Metode yang digunakan dalam penelitian ini adalah metode deskriptif. Prosedur pengerjaan meliputi tahap pengambilan sampel, pengenceran, penanaman sampel dilakukan dengan teknik pour plate di cawan petri pada media PDA (Potato Dextrose Agar). Koloni mikrofungi dimurnikan dengan metode titik dan agar miring. Identifikasi mikrofungi dilakukan dengan teknik Moist Chamber. Hasil Penelitian menunjukkan terdapat 4 jenis mikrofungi pada zona intertidal yaitu Cladosporium sp1., Cladosporium sp2., Aspergillus sp., dan Sp1.. Pada zona subtidal terdapat 2 jenis mikrofungi yaitu Fusarium sp. dan Penicillium sp.

Kata Kunci : Intertidal; Mikrofungi; Subtidal.
\end{abstract}

\begin{abstract}
West Coast Pananjung Pangandaran Coastal area is one of the marine areas that have a high level of biodiversity, especially microorganisms. On the west coast of Pananjung Pangandaran Intertidal zone is indicated to have a level of pollution due to the pattern of human activity is much higher than the subtidal zone thus affecting the existence of microorganisms, especially microfungi. The purpose of this research is to isolate and identify the microfungi contained in the intertidal and subtidal waters of the west coast of Pananjung Pangandaran. The method used in this research is descriptive method. Procedures of workmanship include the sampling stage, dilution, planting the sample is done by pour plate technique in petridish on PDA media (Potato Dextrose Agar). Microfungi colonies are purified by the point method and for italics. Microfungi identification is done by Moist Chamber technique. The results showed there are 4 types of microfungi in the intertidal zone Cladosporium sp1, Cladosporium sp2, Aspergillus sp., and Sp1 .. In the subtidal zone there are 2 types of microfungi namely Fusarium sp. and Penicillium sp.
\end{abstract}

Keywords : Intertidal; Microfungi; Subtidal. 


\section{PENDAHULUAN}

Kawasan pantai umumnya memiliki pembagian zona, salah satu zonasi yang ada dikawasan pantai yaitu zona litoral. Pada dasarnya zona litoral merupakan zona dangkal dimana pada zona ini terjadi pertemuan antara air laut dan daratan. Zona litoral dapat dikategorikan menjadi 3 zonasi yaitu zona supratidal, intertidal, dan subtidal (Awaluddin et al., 2012; Novianti et al., 2016). Zona intertidal dikenal sebagai zona pasang surut yang letaknya paling pinggir pada ekosistem pantai dan berada dikawasan air tinggi (high water) dan air rendah (low water) (Hari Nugroho, 2012; Supratman et al., 2018; Yulianda et al., 2013).

Zona subtidal merupakan zonasi litoral yang keberadaannya terendam air (daerah yang selalu terendam air tanpa mengalami pasang surut), sehingga pergerakan materi organiknya sangat rendah. Zona intertidal memiliki kedalaman 0-60 m dan subtidal berada di kedalaman 60-150 m. Pergerakan materi organik ini nantinya akan mempengaruhi jenis keanekaragaman spesies (Awaluddin et al., 2012; Novianti et al., 2016; Yulianda et al., 2013).

Keanegaraman makhluk hidup pada zona ini sangat tinggi hal ini dipengaruhi akibat terjadinya pasang surut air yang memicu pergerakan bahan organik terakumulasi pada zona intertidal serta supratidal. Namun, karena letaknya yang cendrung dekat dengan bibir pantai dan aktivitas manusia sehingga pada kondisi ekstrim tertentu keanekaragaman makhluk hidup pada zona ini rentan dipengaruhi oleh aktivitas manusia dan pasang surut air (Awaluddin et al., 2012; Hari Nugroho, 2012; Yulianda et al., 2013).
Kawasan Pantai Pangandaran yang berada di Penanjung Pangandaran termasuk kedalam wilayah Cagar Alam dan Taman Wisata Alam Penanjung Pangandaran. Selain berfungsi sebagai tempat perindungan kawasan ini juga difungsikan sebagai tempat tinggal masyarakat sampai sebagai tempat laboratorium alam (Rosada et al., 2017). Beberapa dekade belakangan ini aktivitas manusia yang ada disekitar kawasan tersebut terus meningkat dan diikuti dengan kualitas lingkungan yang semakin menurun. Hal ini tentu saja berdampak langsung terhadap keanekaragaman spesies disana khususnya mikrofungi.

Mikrofungi atau yang kita kenal dengan fungi berukuran mikroskopis sangat besar jumlahnya dialam. Mikrofungi memiliki ciri-ciri yang sama dengan fungi pada umumnya yaitu tidak berklorofil (Wulandari, 2018). Salah satu peranan utama fungi pada suatu ekosistem adalah sebagai agen decomposer. Identifikasi fungi selain dijadikan sebagai bahan informasi namun juga termasuk dalam slaah satu hal terpenting dalam deklarasi millennium dari seluruh kepala negara yang berlangsung di New York tahun 2008 salah satu isinya kelestarian lingkungan dengan mengurangi atau mengantisipasi laju berkurangnya keanekaan hayati (Solle et al., 2018)

Pada mikrofungi laut terdapat 2 sifat yaitu obligat dan fakultatif. Obligat saat mikrofungi bersporulasi dilaut sedangkan fakultatif yaitu bersporulasi didarat maupun air tawar namun dapat tumbuh di laut (Pang et al., 2016)

Banyak jenis mikrofungi laut yang telah diisolasi dan memiliki sejumlah 
potensi. Mikrofungi laut merupakan produsen yang memiliki potensi untuk menghasilkan senyawa bioaktif yang mungkin dimilikinya dan dapa diaplikasikan dalam bidang farmakologi dan obat-obatan (Hong et al., 2015; Pang et al., 2016). Oleh karena itu, penulis tertarik untuk melakukan penelitian mengenai diversitas mikrofungi di panatai barata Pananjung Pangandaran.

\section{BAHAN DAN METODE}

Metode yang digunakan dalam penelitian ini adalah metode deskriptif dengan menggunakan dua tahap. Tahap pertama isolasi mikrofungi dengan pengenceran sampel air laut dari zona intertidal dan subtidal yang dikultur kedalam medium agar. Tahap kedua adalah identifikasi mikrofungi.

\section{Pengambilan Sampel}

Pengambilan sampel air laut pada zona intertidal diambil dari jarak $1 \mathrm{~m}$ dari pantai dengan kedalaman $0 \mathrm{~m}$ yaitu dengan cara menunggu datangnya ombak pantai dan mengarahkan botol sampel berlawanan dengan arah datangnya ombak. Sampel air laut pada zonasi sub tidal diambil dari jarak $250 \mathrm{~m}$ dari pantai dengan kedalaman 5-7 $\mathrm{m}$ yaitu dengan cara mencelupkan botol sampel steril dengan bantuan tali rafia kedalam perairan

\section{Isolasi Mikrofungi}

Isolasi mikrofungi laut pada zona intertidal dan subtidal dilakukan dengan teknik pour plate agar. Pengambilan sempel dilakukan dengan menggunakan botol sampel steril. Selanjutnya sampel air laut dari kedua zonasi di encerkan sampai
$10^{-2}$. Setelah itu, ketiga pengenceran $\left(10^{0}, 10^{-1}\right.$, dan $\left.10^{-2}\right)$ ditanam pada media PDA (Potato Dextrose Agar) dan diinkubasi selama 3-6 hari dengan suhu ruang. Isolat murni didapat dengan cara mengambil hifa mukrofungi dengan ose steril dan dipindahkan kedalam petridish yang telah berisi PDA dengan teknik titik (metode titik) pada permukaan agar dan di streak pada permukaan agar miring ditabung reaksi.

Identifikasi Mikrofungi

Pada pengamatan makroskopis mikrofungi meliputi warna koloni, bentuk koloni dalam cawan petri (konsentris dan tidak konsentris), dan tekstur koloni. Untuk mengidentifikasi fungi secara mikroskopis dilakukan dengan metode moist chamber. Pengamatan mi-kroskopis pada mikrofungi meliputi warna hifa dan konidia (gelap atau hialin transparan), ada atau tidaknya konidia, bentuk konidia (bulat, lonjong, berantai atau tidak beraturan), ada tidaknya septa pada hifa (bersekat atau tidak bersekat), dan pertumbuhan hifa (bercabang atau tidak bercabang). Metode moist chamber dilakukan dengan meng-gunakan cawan petri steril yang didalamnya sudah dialasi kertas saring dan terdapat kaca objek dan kaca penutup.

\section{HASIL DAN PEMBAHASAN}

Berdasarkan Tabel 1 dan 2 didapatkan 6 jenis mkrofungi dengan 4 jenis berasal dari zona intertidal dan 2 jenis pada zona subtidal. Pada intertidal ditemukan mikrofungi dari genus Cladosporium sp1., Cladosporium sp2., 
Tabel 1. Ciri-ciri makroskopis mikrofungi hasil isolasi dari kedua zona

\begin{tabular}{|c|c|c|c|}
\hline \multirow{2}{*}{ Isolat No } & \multicolumn{2}{|l|}{ Morfologi Koloni } & \multirow[b]{2}{*}{ Zona } \\
\hline & Warna & Elevasi & \\
\hline $\mathrm{S} 1.1 \mathrm{P} 10^{0}$ & Hijau dengan hifa berwarna putih & Filamentous & \multirow{4}{*}{ Intertidal } \\
\hline $\mathrm{S} 1.2 \mathrm{P} 10^{0}$ & $\mathrm{Hijau}$ & Filamentous & \\
\hline $\mathrm{S} 1.3 \mathrm{P} 10^{0}$ & Putih dengan bagian atas agak kehijauan & Filamentous & \\
\hline $\mathrm{S} 1.4 \mathrm{P} 10^{-2}$ & Putih kecoklatan & Filamentous & \\
\hline $\mathrm{S} 2.5 \mathrm{P} 10^{-1}$ & Putih-Krem & Circular & \multirow{2}{*}{ Subtidal } \\
\hline S2.6P10 ${ }^{-2}$ & Hijau pada bagian tengahnya dan pinggirannya berhifa putih & Cembung & \\
\hline \multicolumn{3}{|c|}{ Sumber: Data primer, 2017} & \\
\hline \multicolumn{3}{|c|}{ Tabel 2. Karakteristik mikrofungi hasil moist chamber } & \\
\hline Isolat No & \multicolumn{2}{|c|}{ Karakteristik } & Zonasi \\
\hline $\mathrm{S} 1.1 \mathrm{P} 10^{0}$ & \multicolumn{2}{|c|}{$\begin{array}{l}\text { Konidia berbentuk bulat memanjang dengan warna hijau kecoklatan, dan } \\
\text { konidiofor berwarna lebih gelap dari konidia }\end{array}$} & \multirow{4}{*}{ Intertidal } \\
\hline $\mathrm{S} 1.2 \mathrm{P} 10^{0}$ & \multicolumn{2}{|c|}{$\begin{array}{l}\text { Konidia berbentuk bulat memanjang dengan warna hijau dan konidiofor } \\
\text { berwarna lebih gelap dari konidia }\end{array}$} & \\
\hline $\mathrm{S} 1.3 \mathrm{P} 10^{0}$ & \multicolumn{2}{|c|}{$\begin{array}{l}\text { Hifa bersekat atau memiliki septat, bentuk vesikel melonjong, dan konidia } \\
\text { berbentuk bulat }\end{array}$} & \\
\hline $\mathrm{S} 1.4 \mathrm{P} 10^{-2}$ & \multicolumn{2}{|c|}{ Hifa tidak bersepta, bentuk memanjang dan tidak bercabang } & \\
\hline S2.5P $10^{-}$ & \multicolumn{2}{|c|}{$\begin{array}{l}\text { Sporangiofor memanjang pada bagian ujung dan berbentuk sedikit membulat } \\
\text { dengan spora yang terpisah berbentuk lonjong pipih. }\end{array}$} & \multirow[b]{2}{*}{ Subtidal } \\
\hline $\mathrm{S} 2.6 \mathrm{P} 10^{-2}$ & \multicolumn{2}{|c|}{$\begin{array}{l}\text { Hifa yang tidak bersekat (aseptat), konidiofor bercabang, dan konidia } \\
\text { berbentuk bulat }\end{array}$} & \\
\hline
\end{tabular}

Sumber: Data primer, 2017

Aspergillus sp. dan Sp1 (Belum teridentifikasi. Sedangkan, pada zona subtidal ditemukan mikrofungi dari genus Fusarium sp. dan Penicillium sp.

Berdasarkan ciri fungi diatas pada genus Cladosporium sp1 dan Cladosporium sp 2 zona intertidal di temukan perbedaan morfologi makroskopisnya pada pengenceran $10^{\circ}$. Perbedaan ciri morfologi koloni ini dapat dilihat pada Gambar 1 dan Gambar 2. Perbedaan tipe morfologi ini menunjukkan terdapat 2 macam Cladosporium dizonasi intertidal pantai Pangandaran. 

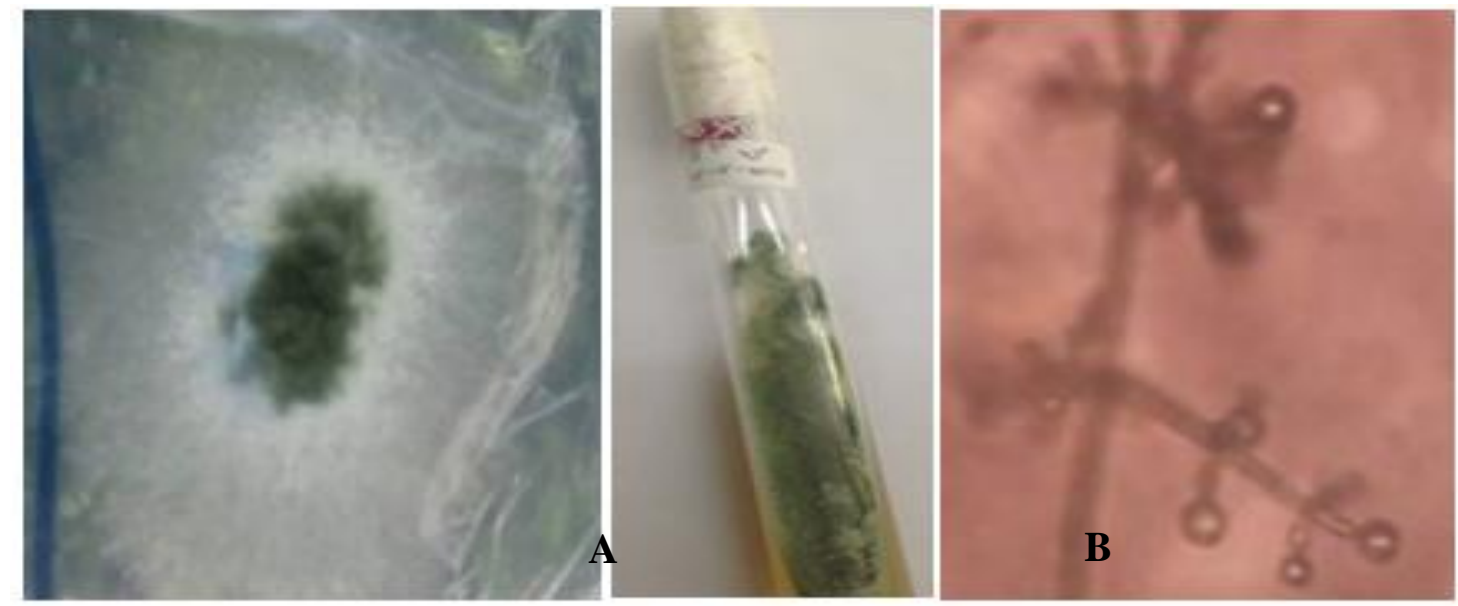

Gambar 1. Cladosporium sp1. (A) struktur makroskopis (B) struktur mikroskopis dengan perbesaran $400 x$
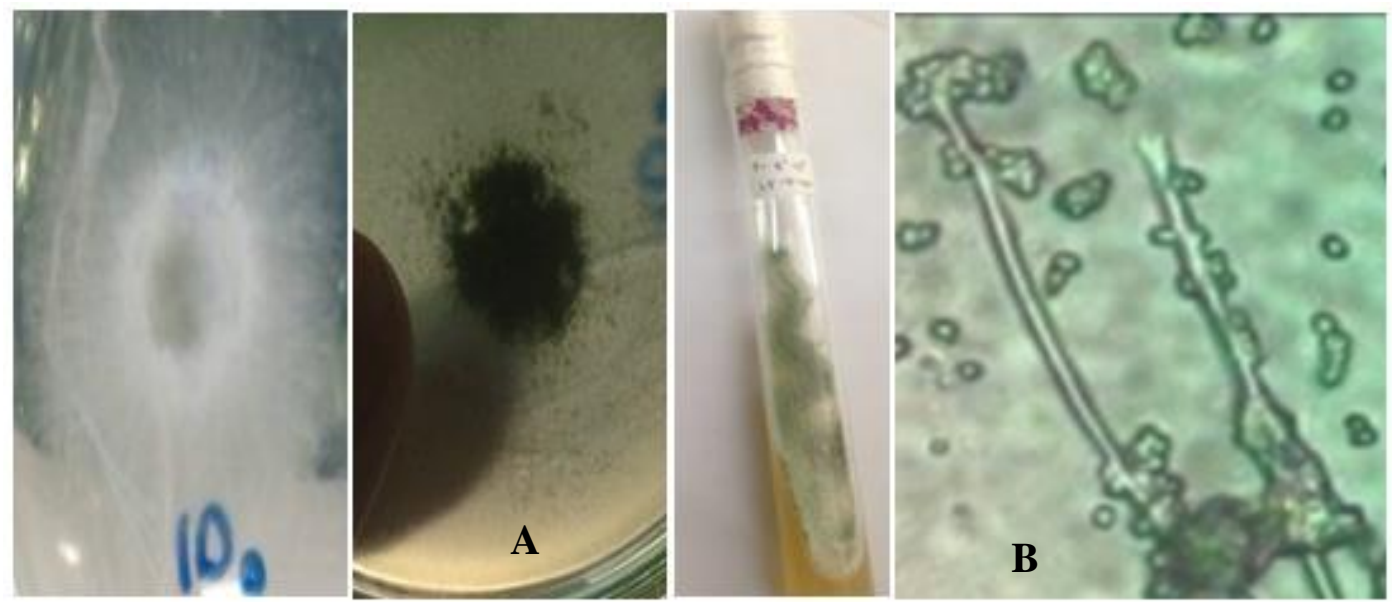

Gambar 2. Cladosporium sp2. (A) struktur makroskopis (B) struktur mikroskopis dengan perbesaran 400x

Berbeda dengan Cladosporium sp1.,Cladosporium sp2 memiliki karakter morfologi makroskopis, yaitu pada tahap awal pertumbuhan koloni berwarna putih dengan tekstur seperti powder namun, pada umur biakan 48 jam koloni berubah menjadi berwarna hijau. Pada bagian dasarnya berwarna hijau kehitaman. Sedangkan secara mikroskopis dengan perbesaran 1000x memiliki konidia yang berbentuk bulat dengan warna hijau kecoklatan, dan konidiofor berwarna lebih gelap dari konidia.

Ciri morfologi Cladosporium yang ditemukan memiliki kesamaan dengan penelitian yang telah dilakukan oleh Ogórek et al., 2012; Yusuf et al., 2016, dimana koloni Cladosporium memiliki konidia yang lebat sehingga pada permukaannya membentuk serbuk halus seperti beludru dengan koloni berwarna abu kecoklatan tua sampai hijau kehitaman.

Pada bagian konidiofor membesar secara terminal atau interkalar yang memanjang secara geniculate. Ramokonidia erletak di bawah (basis) serta memiiki septa 1-2 dengan bentuk 
silindris. Pada mikrofungi ini konodia berbentuk elips hingga silindris dengan dinding yang halus hingga kasar (verruculose) (Corinaldesi et al., 2017; Yusuf et al., 2016).

Sifat hidup Cladosporium yang kosmopolit memungkinkan persebarannya dapat ditemukan diberbagai lokasi dengan syarat faktor fisik yang sangat mendukung untuk mikrofungi ini berkembang. Setelah adanya beberapa kali pertinjauan mengenai takson dari kelompok ini didapat habitat dari mikrofungi jenis ini kebanyakan organisme saprobe. Selain itu genus dari mikrofungi ini diduga memiliki sifat antagonis terhadap beberapa fungi patogen,salah satu contoh yang terjadi yaitu hubungan antagonis antara Cladosporium spp. dengan patogen rust (Ogórek et al., 2012; Torres et al., 2017).

Umumnya Cladosporium yang ditemukan di tanah cenderung bersifat patogen terhadap inangnya, sehingga menurunkan produksi maupun menghambat metabolisme inang. Namun, beberapa Cladosporium yang ditemukan di perairan khususnya di laut memiliki beberapa khasiat membantu di bidang farmakologi.

Spesies Cladosporium telah terbukti memiliki kemampuan untuk menghasilkan berbagai produk alami, di antaranya melanin yang merupakan pigmen yang memberi koloni fungi penampilan khas berwarna gelap. Produk alami lain yang diisolasi dari spesies Cladosporium adalah senyawa bioaktif seperti antifungi cladosporides, faktor pertumbuhan tanaman cotylenins (calphostins yang secara spesifik menghambat protein kinase $\mathrm{C}$, dan cladosporin menunjukkan spektrum aktivitas yang luas termasuk antifungi, antibakteri, insektisida, dan fitotoksik (Corinaldesi et al., 2017; Silber et al., 2014).
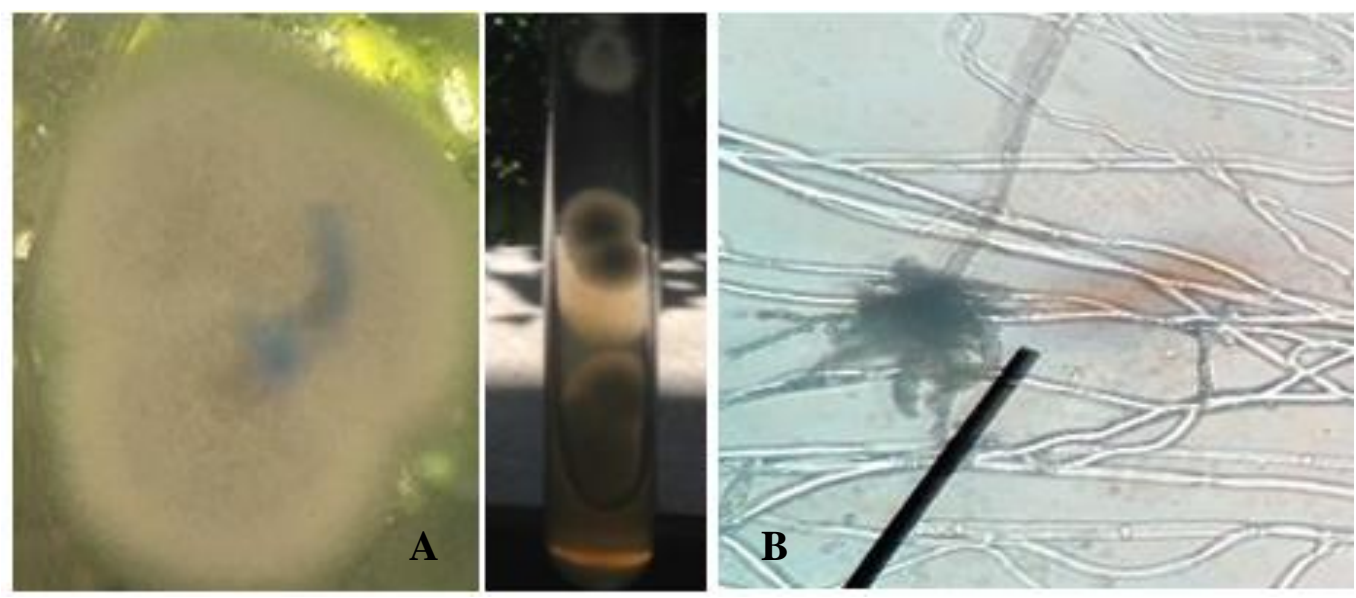

Gambar 3 Aspergillus sp. (A) struktur makroskopis (B) struktur mikroskopis dengan perbesaran $400 x$

Spesies kedua yang ditemukan pada zona intertidal yaitu Aspergillus sp. (gambar 3). Karakteristik morfologi makroskopis mikrofungi Aspergillus sp. koloninya berwarna putih dengan bagian atas yang sedikit berwarna kehijauan, kecil dan hifa masih sedikit, Aspergillus sp. memiliki hifa bersekat atau memiliki 
septat, bentuk vesikel melonjong, dan konidia berbentuk bulat.

Menurut penelitian yang telah dilakuakan oleh Fathoni et al. ( 2017), dimana salah satu genus Aspergillus yang didapat memiliki ciri makroskopis yaitu koloni yang berwarna hijau dengan tekstur koloni seperti datar seperti beludru. Bentuk koloni yang bulat dengan tepi yang rata. Pada pengamatan mikroskopisnya hifa bersepta, dengan bentuk konodia bulat sampai dengan semi bulat berwarna hijau, berdinding kasar vesikula berbentuk gada dan konidiofor tunggal.

Aspergillus sp. ditemukannya di air laut dikarenakan sifat Aspergillus yang tergolong mikrofungi yang bersifat kosmopolitan di alam. Hal ini didukung oleh Prakash \& S.N. (2014), yang menyatakan bahwa Aspergillus adalah fungi berfilamen, kosmopolitan dan dapat ditemukan bebas dialam. Banyak spesies baru kemungkinan ditemukan dari beragam habitat, seperti tanaman hutan tropis dan tanah, yang terkait dengan serangga dan lingkungan.

Aspergillus selain berperan sebagai sumber penyakit pada tanaman namun memiliki sifat antagonis yang dapat menghambat persebaran beberapa penyakit. Spesies Aspergillus diketahui menghasilkan spektrum mycotoxins yang luas termasuk aflatoksin, sterigmatokista dan ochratoksin, yang merupakan agen penyebab beberapa efek karsinogenik, hepatogenik, nefrogenik, dan imunosupresif (Gautam \& Bhadauria, 2012).

Poliketida merupakan salah satu produk alami yang dapat dihasilkan dari proses biologis. Saat ini kebanyakan enzim yang terlibat dalam proses biosintesis berasal dari poliketida yang tidak tereduksi (aromatik) sedangkan, sebagian tereduksi dan sangat tereduksi. Beberapa poliketida fungi memiliki aktivitas antikanker termasuk kedalamnya family statin. Statin merupakan penghambat sintesis kolestrol yang umum digunkaan dalam pengobatan klinis hiperkolesterolemia dan penyakit kadriovaskular. Salah satu family yang dapat menghasilkan statin adalah dari golongan fungi Aspergillus spp. dan Candida spp. (Bladt et al., 2013).
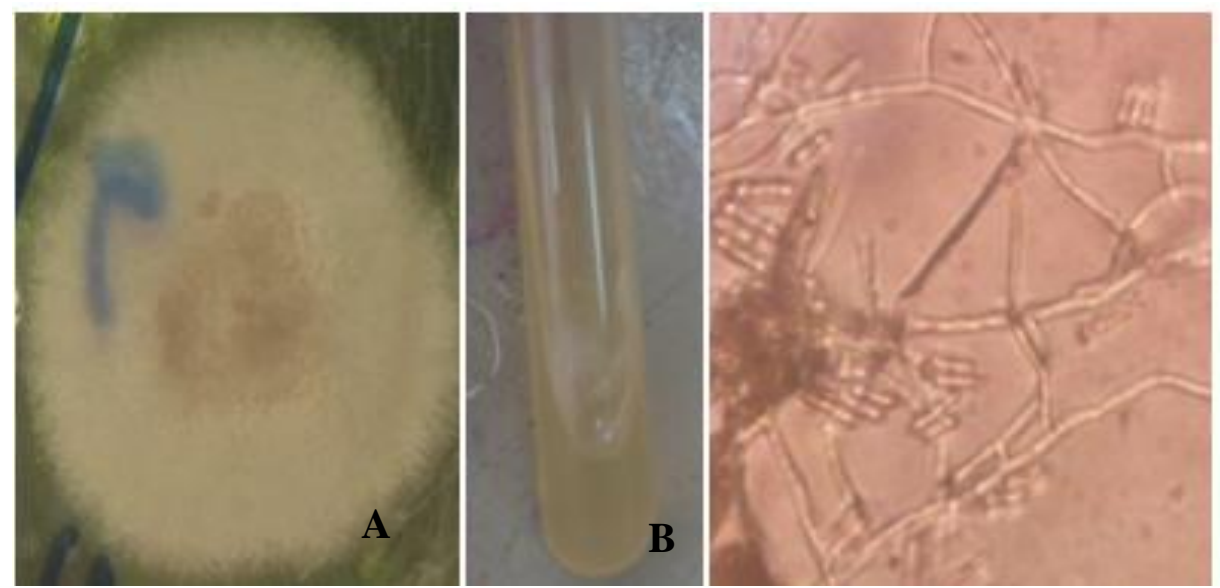

Gambar 4 Sp 1. (A) struktur makroskopis (B) struktur mikroskopis dengan perbesaran $400 x$ 
Spesies ketiga yang ditemukan pada zona intertidal yaitu spesies 1 (Sp1). Karakteristik fungi sp1. koloninya berwarna putih dengan ukuran koloni yang kecil serta berbentuk bulat dan bagian belakang berwarna krem elevasi cembung dan bersifat filamenteous. Sedangkan secara mikroskopis dengan perbesaran 400x hifa memiliki septa dan memiliki cabang. Selain itu, terlihat sporangium yang berbentuk seperti kapsul (Gambar 4)

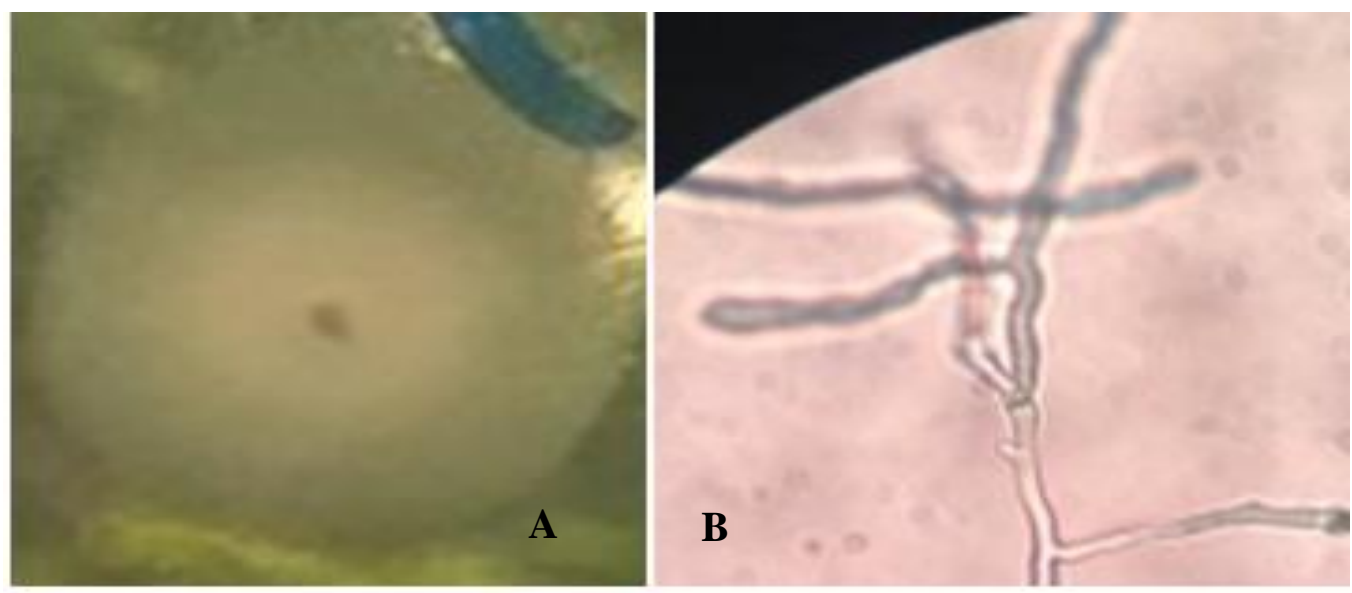

Gambar 5. Fusarium sp. (A) struktur makroskopis (B) struktur mikroskopis dengan perbesaran $400 x$

Genus Fusarium sp. Ditemukan pada zona subtidal (Gambar 5). Pengamatan mikroskopis dengan perbesaran 400x didapat ciri-ciri sebagai berikut Sporangiofor memanjang pada bagian ujung dan berbentuk sedikit membulat dengan spora yang terpisah berbentuk lonjong pipih.

Ciri khusus genus Fusarium sp. Memiliki tubuh buah atau bantalan stromatik dengan konidia hymenium pada permukaannya. Makrokonidia melengkung berbentuk seperti kano dengan kadang menonjol seperti kaki tambahan pada sel basal, dengan bagian septa yang melintang. Mikrokonidia berbentuk bulat telur seperti silinder serta sel-sel konidiogen berbentuk bulat (Wulandari, 2018).

Fusarium sp. merupakan salah satu fungi yang mempunyai sebaran yang sangat luas dengan jenis yang beragam. Fungi Fusarium dianggap sangat merugikan karena dapat menginfeksi tumbuhan. Genus Fusarium sp. adalah patogen tular tanah yang termasuk Hyphomycetes. Fungi ini menghasilkan makrokonidia, mikrokonidia, dan klamidiospora. Sebagian besar dari genus ini merupakan fungi saprofit yang umumnya terdapat di dalam tanah, tetapi ada juga yang bersifat parasite (Ngittu et al., 2014).

Keberadaan genus mikrofungi ini pada perairan subtidal dapat diakibatkan pergerakan air laut yang cukup tinggi didaratan. Hal ini mengakibatkan spora fungi tersebut ikut terbawa arus dan mengendap pada bagian bawah perairan. Jika sekitar lingungan hidup mendukung untuk mikrofungi ini tumbuh, maka akan terbentuk perkembangan vegetatif pada mikrofungi tersebut. 

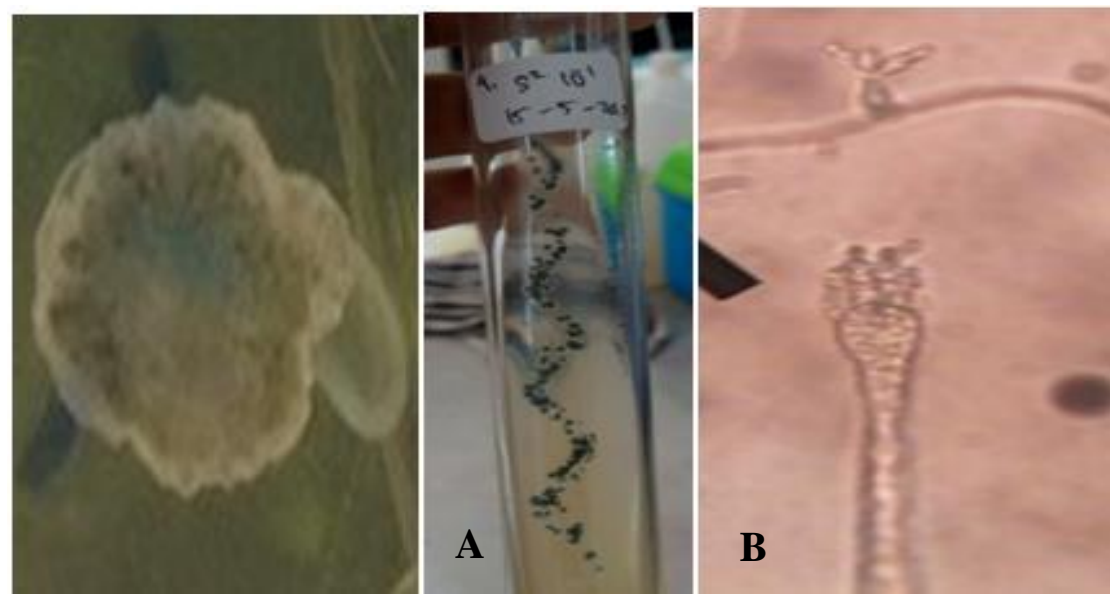

Gambar 6 Penicillium sp. (A) struktur makroskopis (B) struktur mikroskopis dengan perbesaran $400 x$

Spesies kedua yang ditemukan pada zona subtidal yaitu Penicillium sp.. Karakteristik morfologi Penicillium sp. secara makroskopis adalah koloninya berwarna hijau dengan tepi putih yang dikelilingi oleh hifa tipis, serta pada bagian dasarnya berwarna putih kekuningan. Sedangkan secara mikroskopis dengan perbesaran 400x, Penicillium sp. memiliki hifa yang tidak bersekat (aseptat), konidiofor bercabang, dan konidia berbentuk bulat.

Menurut penelitian yang telah dilakukan oleh Ristiari et al. (2018), genus Penicillium memiliki ciri khas makroskopis berupa koloni yang awalnya berwarna putih kemudian berubah menjadi hijau kebiruan, abu-abu kehijauan bahkan terkadang koloni tersebut dapat berwarna kuning kemerahan. Ciri mikroskopis pada mikrofungi ini yaitu hifa berbentuk hialin, konia bulat, bersifat uniseluler terkadang dijumpai sekumpulan fialid.

Penicillium spp., genus tersebut dapat tumbuh dengan cepat dan bersifat antagonistik terhadap fungi lain. Mekanisme antagonis fungi tersebut terjadi dengan cara kompetisi, mikoparasitik, dan antibiosis. Penicillium sp. dapat melindungi tumbuhan terhadap patogen tumbuhan dan meningkatkan pertumbuhan tumbuhan yang dimasukkan sebagai fungi pemacu pertumbuhan tumbuhan. Berdasarkan paparan tersebut, Penicillium merupakan fungi antagonis yang mampu melawan fungi patogen; mikrofungi ini juga memiliki peranan penting didunia kesehatan seperti yang kita tau beberapa kandungan mikotoksin dalam Penicillium dapat digunakan sebagai antibiotic maupun antikanker (Bladt et al., 2013; Budiarti, 2014).

Diantara organisme laut, mikroorganisme, termasuk fungi, protista mirip fungi (seperti thraustochytrids) dan bakteri, telah menarik perhatian besar sebagai produsen senyawa metabolit yang potensial. Banyaknya senyawa dari bakteri dan fungi yang berasal dari laut seperti poliketida, alkaloid, peptida, protein, lipid, mikosporin, dan asam amino seperti mikosporin, glikosida, isoprenoid, dan hibrid memiliki potensi besar dalam kosmeceutis dan kosmetik karena mereka menunjukkan pelindung foton, anti aktivitas penuaan, anti-mikroba, antioksidan, antikanker dan pelembab 
(Corinaldesi et al., 2017; Mayer et al., 2011; Silber et al., 2014).

Faktor yang Mempengaruhi Diversitas Mikrofungi

Perbedaan hasil dari zona intertidal dan subtidal dapat disebabkan adanya beberapa perbedaan dari faktor fisik yang menyebabkan suatu keadaan dimana kondisi tersebut lebih mendukung untuk suatu genus mikrofungi untuk dapat tumbuh. Menurut Bernadip et al. (2014), jika kondisi $\mathrm{pH}$ tinggi, maka akan menjadikan kondisi lingkungan yang tidak sesuai untuk perkembangan jamur, seperti mengganggu dalam pembentukan spora.

Faktor suhu juga menunjukkan adanya pengaruh dari jumlah diversitas fungi yang dihasilkan. Hal ini dijelaskan juga oleh Fety et al. (2015), suhu lingkungan yang optimum bagi pertumbuhan fungi berkisar $25^{\circ} \mathrm{C}-30^{\circ} \mathrm{C}$ dan suhu maksimum $25^{\circ} \mathrm{C}-40^{\circ} \mathrm{C}$, sedangkan kelembaban yang optimal bagi pertumbuhan fungi, yaitu di bawah $80 \%$.

Ketersediaan bahan organik pada suatu lingkungan hidup juga dapat memepengaruhi ketersedian mikrofungi yang ada di laut. Fungi yang hidup dilaut sangat dipengaruhi pertumbuhannya dengan adanya zat oeganik. Pergerakan ombak laut yang intens memiliki persebaran bahan organik yang lebih tinggi bila dibandingkan dengan suatu zona yang memiliki sedikit ombak (Radjasa, 2015).

Perbedaan hasil diversitas mikrofungi yang didapatkan dari kedua zona yaitu intertidal berjumlah 3 genus mikrofungi (Cladosporium, Aspergillus, dan Sp1) sedangkan, pada subtidal hanya berjumlah 2 genus mikrofungi (Fusarium dan Penicillium). Dari data hasil tersebut antara zona intertidal dan zona subtidal tidak menunjukkan perbedaan yang signifikan dari jumlah genus yang dapat diisolasi. Namun, bila ditinjau dari jenis genus yang dapat diisolasi dari kedua zona ini tidak ditemukan jenis genus yang sama antara zona intertidal dengan zona subtidal.

\section{KESIMPULAN}

Pada daerah intertidal dan subtidal pantai Barat Penanjung Pangandaran ditemukan 5 jenis genus mikrofungi diantaranya Cladosporium, Aspergillus, sp1., Fusarium, dan Penicillium. Perbandingan diversitas antara zona intertidal dengan zona subtidal hanya dapat dibedakan dengan genus mikrofungi yaitu pada zona intertidal ditemukan genus Cladosporium, Aspergillus, dan Sp1 pada zona subtidal hanya ditemukan Fusarium, dan Penicillium.

\section{UCAPAN TERIMAKASIH}

Terimakasih kepada Ibu Dr. Nia Rossiana, MS., selaku dosen pembimbing yang selalu memberikan saran, kritik, semangat dan nasihat serta bersedia untuk meluangkan waktunya selama penelitian ini berlangsung, terimakasih juga kepada Ibu Dr. Ida Indrawati, M.Si. selaku dosen Pembimbing Lapangan yang telah membantu dan mengarahkan masukan dan dukungannya selama penelitian ini.

\section{DAFTAR PUSTAKA}

Awaluddin, H. H., A., S. A., Jones, E. B. G., \& Kai-Lai, P. (2012). Observation on the Biodiversity of SandAssociated Marine Fungi from East 
and West Coast of Peninsular Malaysia. University of Malaya.

Bernadip, B. R., Hadiwiyono, \& Sudadi. (2014). Keanekaragaman Jamur dan Bakteri Rizosfer Bawang Merah Terhadap Patogen Moler. Sains Tanah-Jurnal IImu Tanah Dan Agroklimatologi, 11(1), 52-60.

Bladt, T. T., Frisvad, J. C., Knudsen, P. B., \& Larsen, T. O. (2013). Anticancer and antifungal compounds from Aspergillus, Penicillium and other filamentous fungi. In Molecules (Vol. 18, Issue 9). https://doi.org/10.3390/molecules 180 911338

Budiarti, L. (2014). Kelimpahan Cendawan Antagonis pada Rhizosfer Tanaman Kacang Panjang ( Vigna sinensis ( $L$ .) Savi ex Hassk .) di Lahan Kering Indralaya Sumatera Selatan Abundance of Antagonist Fungus on Cowpea Rhizosfer ( Vigna sinensis ( L.) Savi ex Hassk .) in The Dry . September, 1-11.

Corinaldesi, C., Barone, G., Marcellini, F., Dell'Anno, A., \& Danovaro, R. (2017). Marine microbial-derived molecules and their potential use in cosmeceutical and cosmetic products. Marine Drugs, 15(4), 1-21. https://doi.org/10.3390/md15040118

Fathoni, R., Radiastuti, N., \& Wijayanti, F. (2017). Identifikasi Jenis Cendawan pada Kelelawar (Ordo Chiroptera) di Kota Tangerang Selatan. Jurnal Mikologi Indonesia, 1(1), 28. https://doi.org/10.46638/jmi.v1i1.11
Fety, Khotimah, S., \& Mukarlina. (2015). Uji Antagonis Jamur Rizosfer Isolat Lokal terhadap Phytophthora sp. yang Diisolasi dari Batang Langsat (Lansium domesticum Corr.). Jurnal Protobion, 4(1), 218-225.

Gautam, A. K., \& Bhadauria, R. (2012). Characterization of Aspergillus species associated with commercially stored triphala powder. Characterization of Aspergillus Species Associated with Commercially Stored Triphala Powder, 11(104), 16814-16823. https://doi.org/10.5897/AJB11.2311

Hari Nugroho, S. (2012). Morfologi Pantai, Zonasi dan Adaptasi Komunitas Biota Laut di Kawasan Intertidal. Oseana, XXXVII, 11-21.

Hong, J. H., Jang, S., Heo, Y. M., Min, M., Lee, H., Lee, Y. M., Lee, H., \& Kim, J. J. (2015). Investigation of marinederived fungal diversity and their exploitable biological activities. Marine Drugs, 13(7), 4137-4155. https://doi.org/10.3390/md13074137

Mayer, A. M. S., Rodríguez, A. D., Berlinck, R. G. S., \& Fusetani, N. (2011). Marine pharmacology in 2007-8: Marine compounds with antibacterial, anticoagulant, antifungal, anti-inflammatory, antimalarial, antiprotozoal, antituberculosis, and antiviral activities; Affecting the immune and nervous system, and other miscellaneous mec. Comparative Biochemistry and Physiology - C Toxicology and Pharmacology, 
153(2), $\quad$ 191-222. https://doi.org/10.1016/j.cbpc.2010.0 8.008

Ngittu, Y. S., Mantiri, F. R., \& Tallei, T. E. (2014). Identifikasi Genus Jamur Fusarium Yang Menginfeksi Eceng Gondok (Eichhornia Crassipes) Di Danau Tondano. Pharmacon, 3(3), 156-161.

https://doi.org/10.35799/pha.3.2014.5 321

Novianti, M., Rusyana, A., \& Romdah Romansyah. (2016). Keanekaragaman Jenis Echinodermata Pada Berbagai Macam Substrat Pasir, Lamun Dan Karang Di Perairan Pantai Sindangkertacipatujah Tasikmalaya. Jurnal Pendidikan Biologi (Bioed), 4(1), 19-26.

Ogórek, R., Lejman, A., Pusz, W., Miłuch, A., \& Miodyńska, P. (2012). Charakterystyka i taksonomia grzybów z rodzaju Cladosporium. Mikologia Lekarska, 19(2), 80-85.

Pang, K. L., Overy, D. P., Jones, E. B. G., Calado, M. da L., Burgaud, G., Walker, A. K., Johnson, J. A., Kerr, R. G., Cha, H. J., \& Bills, G. F. (2016). 'Marine fungi' and 'marinederived fungi' in natural product chemistry research: Toward a new consensual definition. Fungal Biology Reviews, 30(4), 163-175. https://doi.org/10.1016/j.fbr.2016.08.0 01

Prakash, R., \& S.N., J. (2014). Basics of the Genus Aspergillus. International
Journal of Research in Botany, 4(2), 26-30.

Radjasa, O. K. (2015). Marine Fungi: The Untapped Diversity of Marine Microorganisms. Journal of Coastal Zone Management, 18(1), 3350. https://doi.org/10.4172/2473$3350.1000 \mathrm{e} 110$

Ristiari, N. putu nila, Julyasih, ketut srie marhaeni, \& Suryanti, ida ayu putu. (2018). ISOLASI DAN IDENTIFIKASI JAMUR MIKROSKOPIS PADA RIZOSFER TANAMAN JERUK SIAM (Citrus nobilis Lour.) DI KECAMATAN KINTAMANI, BALI. 6(1), 10-19.

Rosada, K. K., Pribadi, T. D. K., \& Putri, S. A. (2017). Struktur Komunitas Fitoplankton pada Berbagai Kedalaman di Pantai Timur Pananjung Pangandaran. Jurnal Biodjati, 2(1), 30. https://doi.org/10.15575/biodjati.v2i1. 1290

Silber, J., Ohlendorf, B., Labes, A., Wenzel-Storjohann, A., Näther, C., \& Imhoff, J. F. (2014). Malettinin E, an antibacterial and antifungal tropolone produced by a marine Cladosporium strain. Frontiers in Marine Science, 1(AUG), $1-6$. https://doi.org/10.3389/fmars.2014.00 035

Solle, H., Klau, F., \& Nuhamara, S. T. (2018). Keanekaragaman Jamur di Cagar Alam Gunung Mutis Kabupaten Timor Tengah Utara, Nusa Tenggara Timur. Journal of Biota, $3(2), \quad 105$. 
Putri Kumala Dewi, Diversitas Mikrofungi Zona ...

https://doi.org/10.24002/biota.v3i2.18 86

Supratman, O., Farhaby, A. M., \& Ferizal, J. (2018). Kelimpahan Dan Keanekaragaman Gastropoda Pada Zona Intertidal Di Pulau Bangka Bagian Timur. Jurnal Enggano, 3(1), 10-21.

https://doi.org/10.31186/jenggano.3.1 $.10-21$

Torres, D. E., Rojas-Martínez, R. I., Zavaleta-Mejía, E., Guevara-Fefer, P., Márquez-Guzmán, G. J., \& PérezMartínez, C. (2017). Cladosporium cladosporioides and Cladosporium pseudocladosporioides as potential new fungal antagonists of Puccinia horiana Henn., the causal agent of chrysanthemum white rust. PLOS ONE, 12(1), 1-16. https://doi.org/10.1371/journal.pone.0 170782

Wulandari, R. (2018). Investigasi Jenis Mikrofungi Epifit Pada Udang Dan Rajungan Dari Kawasan Budidaya Kota Tanjungpinang. Intek Akuakultur, 2(1), 46-53. https://doi.org/10.31629/intek.v2i1.59 0

Yulianda, F., Yusuf, M. S., \& Prayogo, W. (2013). Zonasi dan Kepadatan Komunitas Intertidal di Daerah Pasang Surut, Pesisir Batuhijau, Sumbawa. Jurnal IImu Dan Teknologi Kelautan Tropis, 5(2), 409-416.

Yusuf, E. S., Nuryani, W., \& Hanudin, N. (2016). Isolasi dan Identifikasi Mikoparasit Utama Pada Karat
Krisan. Jurnal Hortikultura, 26(2), 217.

https://doi.org/10.21082/jhort.v26n2.2

016.p217-222 